\title{
Komunikasi Inovasi dalam Adaptasi Kebiasaan Baru: Studi Deskriptif pada Pelaku Usaha di Provinsi Riau
}

\section{Communication of Innovation in Adapting New Habits: A Descriptive Study on Business Actors in Riau Province}

\author{
Muhammad Badri ${ }^{1, *}$ \\ ${ }^{1}$ Universitas Islam Negeri Sultan Syarif Kasim Riau, 28293, Indonesia \\ *)E-mail korespondensi: muhammad.badri@uin-suska.ac.id \\ Diterima: 7 Oktober 2021 | Disetujui: 4 Januari 2022 | Publikasi online: 19 Januari 2022
}

\begin{abstract}
The prevention of Covid-19 transmission through health protocols called an adaptation of new habits Business actors are one of the groups that are required to implement health protocols. This study aims to determine the communication of innovation and the level of adaptation to new habits among business actors with a descriptive study in Riau Province. This study uses a quantitative approach with a survey method of 220 business actors. This study instrument was built using the theory and concept of communication of innovation. This study found that the highest source of information in communication of innovation was social media, followed by mass media, and interpersonal communication from the government. Most of the respondents stated that health protocol information is an important message so they agree to comply. The adoption rate for health protocol indicators such as providing information to comply with health protocols for workers and customers is high. Likewise, the provision of health protocol facilities such as hand washing facilities, hand sanitizers, and information on maintaining distance. Respondents also confirmed that they would adhere to health protocols until the pandemic was over because in addition to protecting individuals it was also for the sustainability of their businesses.
\end{abstract}

Keywords: Health protocol, information, social media, pandemic, new normal

\section{ABSTRAK}

Pencegahan penularan Covid-19 melalui protokol kesehatan dapat disebut sebagai adaptasi kebiasaan baru. Pelaku usaha merupakan salah satu kelompok yang dituntut untuk menerapkan protokol kesehatan. Penelitian ini bertujuan untuk mengetahui komunikasi inovasi dan tingkat adaptasi kebiasaan baru pada kalangan pelaku usaha dengan studi deskriptif di Provinsi Riau. Penelitian ini menggunakan pendekatan kuantitatif dengan metode survei terhadap 220 pelaku usaha. Instrumen penelitian ini dibangun menggunakan teori dan konsep komunikasi inovasi. Penelitian ini menemukan bahwa sumber informasi komunikasi inovasi paling tinggi yaitu media sosial, diikuti media massa, dan komunikasi interpersonal dari pemerintah. Sebagian besar responden menyatakan, informasi protokol kesehatan merupakan pesan penting sehingga mereka setuju mematuhi. Tingkat adopsi terhadap indikator protokol kesehatan seperti menyediakan informasi untuk mematuhi protokol kesehatan bagi pekerja dan pelanggan tinggi. Begitu juga penyediaan fasilitas protokol kesehatan seperti fasilitas cuci tangan, hand sanitizer, dan informasi menjaga jarak. Responden juga memberi konfirmasi tetap mematuhi protokol kesehatan sampai pandemi usai, karena selain untuk melindungi individu juga untuk keberlanjutan usahanya.

Kata kunci: Protokol kesehatan, informasi, media sosial, pandemi, normal baru

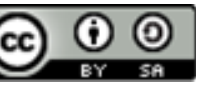

Content from this work may be used under the terms of the Creative Commons Attribution-ShareAlike 4.0 International. Any further distributionof this work must maintain attribution to the author(s) and the title of the work, journal citation and DOI.

Published under Department of Communication and Community Development Science, IPB University and in association with Forum Komunikasi Pembangunan Indonesia and Asosiasi Penerbitan Jurnal Komunikasi Indonesia.

E-ISSN: 2442-4102 | P-ISSN: 1693-3699 


\section{PENDAHULUAN}

Pandemi Corona Virus Disease (Covid-19) sudah lebih setahun melanda Indonesia, jika dihitung sejak laporan kasus pertama yaitu pada 2 Maret 2020. Pandemi tersebut telah memberi efek buruk pada tatanan kehidupan sosial serta menurunkan kinerja ekonomi. Untuk menekan penyebaran Covid-19, pemerintah Indonesia membuat beragam inovasi kebijakan, mulai dari Pembatasan Sosial Berskala Besar (PSBB), Pembatasan Sosial Berskala Mikro (PSBM), hingga Pemberlakuan Pembatasan Kegiatan Masyarakat (PPKM). Namun kebijakan yang berdampak pada penutupan dan pembatasan operasional tempat usaha, tempat ibadah, tempat wisata, hingga sekolah tersebut belum dapat memutus rantai penyebaran Covid-19. Jumlah kasus terkonfirmasi masih terus ada dengan grafik fluktuatif.

Pembatasan mobilitas masyarakat selama Covid-19 berpotensi memicu kecemasan, depresi, dan stres (Megatsari et al., 2020). Salah satu yang paling terdampak Covid-19 yaitu pelaku bisnis. Covid-19 telah menyebabkan perlambatan pembangunan ekonomi global. Banyak perusahaan dipaksa beradaptasi dengan kondisi sulit dengan bertahan dalam kondisi "normal baru" dan mengadopsi pedoman manajerial baru. Keberlangsungan bisnis akan bergantung pada kemampuan untuk beradaptasi dengan pasar baru, yang telah dibentuk oleh pembatasan pergerakan yang diberlakukan oleh hampir semua negara untuk mengekang penyebaran Covid-19. Bisnis kecil dan menengah paling terpukul oleh pandemi, jadi mereka harus segera menemukan kembali diri mereka jika ingin bertahan dalam skenario yang tidak terduga ini. Dalam realitas baru ini, masa depan bisnis tidak pasti, sehingga pengambilan keputusan yang tepat sangat penting untuk memperkuat perusahaan (Carracedo, Puertas and Marti, 2020).

Dalam kondisi krisis Covid-19, kebutuhan pemerintah untuk menghasilkan pendapatan publik dan menemukan jalan keluar dari krisis ekonomi dapat meningkatkan tekanan bagi reformasi pro-bisnis untuk menarik investasi (Cotula, 2021). Covid-19 juga memunculkan kondisi "normal baru" yang merevolusi kebiasaan masyarakat dalam menjalani kehidupan seperti sebelum pandemi (Kirk dan Rifkin, 2020). Pandemi juga menyebabkan kebutuhan terhadap teknologi komunikasi dalam kehidupan sehari-hari semakin intens dan hal ini mendorong pola perilaku baru, yang pada gilirannya berdampak besar pada kebiasaan konsumsi. Bagi pelaku usaha, kondisi ini memerlukan penataan kembali strategi bisnis untuk beradaptasi dengan perubahan pasar (Pantano et al., 2020).

Di sebagian besar negara berpenghasilan rendah dan menengah, Usaha Mikro, Kecil, dan Menengah (UMKM) memainkan peran penting dalam rantai pasokan pangan dan memastikan ketahanan pangan. Saat pandemi, terjadi penurunan penjualan yang disebabkan penutupan langsung gerai ritel dan rendahnya daya beli konsumen. Hal ini terjadi karena perubahan perilaku konsumen terutama penurunan mobilitas konsumen untuk berbelanja bahan makanan. Salah satu cara penting untuk mendukung perusahaan sistem pangan selama pandemi adalah dengan memungkinkan konsumen berbelanja dengan aman. Salah satunya melalui penjualan daring (Nordhagen et al., 2021). UMKM juga yang paling terpukul di semua negara sehingga membutuhkan paket revitalisasi ekonomi khusus (Shaw, Kim dan Hua, 2020).

Untuk kasus di Indonesia, pelaku UMKM juga merupakan kelompok bisnis yang banyak terdampak. Dampaknya bukan hanya karena meluasnya penyebaran Covid-19 saja, tetapi juga terkait dengan kebijakan penerapan protokol kesehatan yang mesti dipatuhi. Pelaku usaha dituntut untuk mematuhi protokol kesehatan seperti menyediakan fasilitas cuci tangan, hand sanitizer, memperluas jarak fisik, kewajiban menggunakan masker, hingga pembatasan waktu operasional. Hal tersebut dapat berdampak pada penambahan biaya operasional, sementara rata-rata pelaku usaha mengalami penurunan transaksi. Perubahan sosial akibat Covid-19 pada pelaku usaha ini menarik diamati dari berbagai perspektif, termasuk komunikasi.

Berdasarkan survei Badan Pusat Statistik (BPS), sebagian besar pelaku usaha telah menerapkan protokol kesehatan, di mana $81.91 \%$ menerapkan physical distancing, $81.87 \%$ menyediakan saran cuci tangan (air, sabun dan hand sanitizer), dan $85.88 \%$ sudah mewajibkan penggunaan masker atau pelindung. Secara rata-rata perusahaan di perkotaan lebih patuh dalam menerapkan protokol kesehatan dibandingkan perusahaan di wilayah kabupaten. Usaha berskala menengah dan besar relatif lebih 
patuh pada penerapan protokol kesehatan di lingkungan kerja dibandingkan usaha berskala kecil dan mikro (Badan Pusat Statistik, 2020a). BPS juga melakukan survei perilaku masyarakat di masa pandemi Covid-19. Hasilnya tingkat kepatuhan responden dalam penerapan protokol kesehatan untuk pencegahan Covid-19 sudah baik, dengan rincian kepatuhan penggunaan masker 91.98\%, penggunaan hand sanitizer $77.71 \%$, mencuci tangan menggunakan sabun $75.38 \%$, menghindari jabat tangan $81.85 \%$, menghindari kerumunan $76.69 \%$, dan menjaga jarak minimal satu meter $73.54 \%$ (Badan Pusat Statistik, 2020b).

Banyak penelitian yang mengambil isu Covid-19 dan perubahan sosial pada konteks perilaku bisnis. Pandemi menyebabkan beberapa gangguan jangka pendek dan menengah, yang harus diadaptasi oleh pelaku bisnis. Misalnya terdapat fenomena para pengecer segera bereaksi terhadap keadaan darurat (Pantano et al., 2020). UMKM yang memiliki cadangan kas sangat rendah rentan dan mungkin tidak dapat bertahan selama wabah Covid-19 yang sedang berlangsung. Oleh karena itu, sangat diperlukan mitigasi terhadap krisis yang sedang berlangsung sekaligus terhadap dampak jangka panjang yang ditimbulkan akibat Covid-19 atau lockdown. Sebagian besar UMKM terdampak parah menghadapi beberapa masalah seperti keuangan, gangguan rantai pasokan, penurunan permintaan, penurunan penjualan, dan penurunan keuntungan. Selain itu, sebagian besar UMKM tidak siap menangani situasi tersebut tidak dapat bertahan jika pembatasan (lockdown) berlangsung lebih dari dua bulan (Shafi, Liu dan Ren, 2020).

Pada kasus bisnis makanan, pandemi Covid-19 telah mengubah relasi konsumen dengan makanan, baik dalam berbelanja, memperbanyak masakan rumahan, melakukan tindakan pencegahan saat berbelanja makanan, pengiriman makanan, dan saat makan di luar. Penelitian menemukan, konsumen yang memiliki kecenderungan memperhatikan keamanan dalam konsumsi makanan cenderung mematuhi tindakan aman makan di luar. Misalnya pemilihan restoran yang bersih dan tidak terlalu ramai, memperhatikan higienitas tangan, menggunakan masker, dan menjaga jarak. Temuan lainnya, untuk mematuhi protokol kesehatan secara maksimal, perlu dukungan staf restoran untuk memastikan jarak sosial dan menyediakan fasilitas cuci tangan yang memadai (Soon et al., 2021).

Isu sosial ekonomi akibat Covid-19 yang banyak dibahas media di Indonesia antara lain terkait dengan menjaga jarak sosial, pembatasan sosial, tindakan sosial, budaya, masalah lain yang terkait dengan sektor sosial (penurunan daya beli masyarakat, konsumsi, dan pemecatan) dan dampak nyata dan masif terhadap pertumbuhan ekonomi. Covid-19 bukan hanya krisis kesehatan global tetapi juga pasar tenaga kerja utama dan krisis ekonomi yang berdampak signifikan terhadap masyarakat (Gandasari and Dwidienawati, 2020). Isu-isu tersebut berkaitan erat dengan persoalan penerapan protokol kesehatan dan keterkaitannya dengan sektor bisnis. Untuk itu, menarik jika melakukan penelitian tentang adaptasi kebiasaan baru pada kalangan pelaku usaha khususnya UMKM.

Adaptasi terhadap kebiasaan baru merupakan kebijakan nasional sebagai respons atas belum berakhirnya pandemi Covid-19 di Indonesia. Pelaku usaha merupakan salah satu sasaran penting kebijakan tersebut karena banyak bersentuhan dengan masyarakat, terutama pelanggan. Banyak pelaku usaha yang menerapkan protokol kesehatan, tetapi masih ada juga yang mengabaikannya. Penelitian ini mendeskripsikan tingkat adopsi adaptasi kebiasaan baru dari perspektif komunikasi inovasi. Kajian komunikasi inovasi menekankan proses komunikasi suatu inovasi atau gagasan baru dan adopsinya pada suatu sistem sosial.

Komunikasi inovasi adalah upaya manusia menggali dan mengembangkan informasi (komunikasi) untuk memperoleh, mengembangkan, menyebarluaskan, atau menghasilkan suatu pembaruan (inovasi) dalam kehidupannya. Tujuan komunikasi inovasi adalah mewujudkan perubahan atau meningkatkan kualitas perilaku menuju kualitas kehidupan yang lebih baik. Melalui komunikasi inovasi diharapkan terjadi perubahan perilaku sehingga menjadi lebih adaptif yang berbeda dengan perilaku sebelumnya. Perubahan tersebut dapat terjadi melalui proses komunikasi inovasi, yaitu melalui penggalian dan pengembangan informasi serta penerapannya yang mengandung muatan inovasi (Sumardjo et al., 2019).

Komunikasi inovasi disebut juga dengan difusi inovasi, yaitu tipe khusus komunikasi yang membahas bagaimana suatu inovasi menyebar dan diadopsi masyarakat. Difusi yaitu proses di mana (1) inovasi; 
(2) dikomunikasikan melalui saluran tertentu; (3) dari waktu ke waktu (4); di antara anggota sistem sosial. Empat elemen utama dalam difusi inovasi adalah inovasi, saluran komunikasi, waktu, dan sistem sosial. Elemen-elemen ini dapat diidentifikasi dalam setiap studi penelitian difusi dan dalam setiap kampanye atau program difusi (Rogers, 2003).

Kajian difusi inovasi memiliki model proses keputusan inovasi yang terbagi menjadi lima tahapan yaitu: (1) pengetahuan, (2) persuasi, (3) keputusan, (4) implementasi, dan (5) konfirmasi. Pada tahap pengetahuan subjek mulai mempelajari inovasi dan fungsinya. Pada tahap persuasi subjek memperoleh pesan yang dapat membentuk sikap terhadap inovasi, menguntungkan atau merugikan. Selanjutnya, tahap keputusan subjek menentukan pilihan mengadopsi atau menolak inovasi. Implementasi dari keputusan jika mengadopsi maka subjek menerapkan inovasi, begitu juga sebaliknya. Terakhir, pada tahap konfirmasi subjek mencari penguatan keputusan yang dipilihnya, sekaligus menentukan apakah melanjutkan atau mengubah keputusannya (Rogers, 2003).

Pendekatan komunikasi inovasi menarik dilakukan karena proses masuknya ide-ide baru (seperti adaptasi kebiasaan baru) ke dalam tatanan sosial masyarakat merupakan proses komunikasi. Gagasan baru dikomunikasikan kepada masyarakat melalui berbagai cara yang semakin lama semakin mendalam sehingga masyarakat dapat memahaminya pada berbagai tingkatan. Mungkin ada yang langsung menerima dengan cepat, menerima namun lambat, bahkan ada yang tetap menolak (Hubeis et al., 2016).

Dalam konteks ini adaptasi kebiasaan baru dapat disebut sebagai inovasi yang dimunculkan untuk merespons perubahan tatanan sosial masyarakat akibat pandemi Covid-19. Sistem sosial yang dijadikan subjek penelitian yaitu kalangan pelaku UMKM. Adaptasi merupakan proses perubahan saat menghadapi lingkungan baru (Aisha dan Mulyana, 2020). Adaptasi kebiasaan baru merupakan terminologi pemerintah Indonesia dalam kampanye tatanan hidup baru agar masyarakat dapat bekerja, belajar, dan beraktivitas dengan produktif dan aman di era pandemi Covid-19. Melalui adaptasi kebiasaan baru, masyarakat diharapkan dapat kembali bekerja, belajar, bersosialisasi, dan melakukan aktivitas lainnya dengan menerapkan protokol kesehatan. Masyarakat dituntut mampu beradaptasi dengan kebiasaan baru di manapun berada, seperti di rumah, di kantor, di sekolah, di tempat ibadah, dan juga di tempat-tempat umum, seperti terminal, pasar, dan mal. Adaptasi kebiasaan baru ini diharapkan menjadi norma individu dan norma masyarakat, meliputi: sering cuci tangan pakai sabun, pakai masker, jaga jarak, istirahat cukup dan rajin olahraga, dan makan makanan bergizi seimbang (Kementerian Kesehatan, 2020).

Kementerian Komunikasi dan Informatika (2020) menjelaskan, adaptasi kebiasaan baru merupakan proses bertahap yang tergantung pada situasi di daerah masing-masing. Indikator penerapan adaptasi kebiasaan baru berupa penerapan protokol kesehatan seperti: (1) Selalu menggunakan masker saat keluar rumah; (2) menghindari menyentuh mata, hidung, dan mulut; (3) Selalu menjaga jarak lebih dari satu meter dari orang-orang saat berada di luar rumah; (4) Sering mencuci tangan dengan sabun selama minimal 20 detik saat berada di tempat tujuan dan tiba di rumah; dan (5) Selalu ikuti perkembangan informasi dan hanya ikuti sumber terpercaya.

Satuan Tugas Penanganan Covid-19 (2020) menerbitkan materi edukasi adaptasi kebiasaan baru bagi pelaku usaha. Tujuannya untuk memastikan karyawan dan pelanggan terlindungi dari penularan virus corona, baik di di tempat kerja, tempat penjualan ataupun tempat umum. Pesan yang disampaikan antara lain: (1) Menyampaikan pada karyawan sakit agar istirahat di rumah meski hanya demam ringan batuk atau pilek; (2) Bila memungkinkan, atur agar karyawan bekerja dari rumah; (3) Menghindari pertemuan besar; (4) Memastikan karyawan mencuci tangan pakai sabun dan air mengalir dengan, tidak bersalaman dan mengikuti etika saat batuk atau bersin; (5) Menyiapkan dispenser cairan pembersih tangan di tempat-tempat penting seperti dekat pintu masuk/ keluar, saklar lampu, tempat makan, kasir, toilet, dan lain-lain; (6) Memastikan sabun dan air mengalir tersedia di toilet; (7) Mengidentifikasi orang-orang berisiko; (8) Membuat kebijakan yang lebih fleksibel yang memungkinkan karyawan bekerja dari rumah; (9) Menghindari perjalanan bisnis dan bila harus, tetap waspada selama perjalanan; (10) Memasang poster-poster pencegahan Covid-19 di tempat kerja; dan (11) Secara teratur bersihkan permukaan benda-benda yang sering disentuh karyawan dengan cairan disinfektan. 
Penelitian ini dilakukan di Provinsi Riau dengan pertimbangan pelaku usaha di provinsi ini relatif heterogen sehingga diharapkan data yang dihasilkan lebih objektif. Berdasarkan survei BPS Provinsi Riau, sebagian besar masyarakat mengetahui tentang kebijakan physical distancing secara detail dan selalu berusaha tetap di rumah. Ketika sedang berada di luar rumah, responden selalu memberitahu orang sekitar bila bergejala, menghindari pertemuan atau berdiri dalam antrean panjang, menghindari naik transportasi umum (termasuk transportasi online), menghindari berjabat tangan, mencuci tangan selama 20 detik dengan sabun, dan memakai masker. Selain itu, responden hampir selalu menjaga jarak setidaknya dua meter dari orang lain ketika di luar rumah, menghindari menyentuh benda/ permukaan benda di area publik, menggunakan hand sanitizer/ disinfektan, dan menghindari menyentuh wajah (BPS Provinsi Riau, 2020).

Temuan di atas masih bersifat umum dan belum menjelaskan tentang adopsi adaptasi kebiasaan baru pada pelaku usaha. Melihat fenomena tersebut penelitian tentang komunikasi inovasi dan adaptasi kebiasaan baru di kalangan pelaku usaha menarik dilakukan, terutama ketika pandemi COVID-19 sudah terjadi satu tahun. Waktu yang cukup lama bagi peradaban modern untuk memecahkan masalah pandemi, padahal masyarakat sudah berada pada era Revolusi Industri 4.0. Penelitian ini bertujuan untuk mengetahui komunikasi inovasi dan tingkat adaptasi kebiasaan baru pada kalangan pelaku usaha dengan studi di Provinsi Riau.

\section{METODE PENELITIAN}

Penelitian dilakukan dengan pendekatan kuantitatif menggunakan metode survei terhadap pelaku usaha di kawasan ibu kota kabupaten dan kota di Provinsi Riau. Dalam penelitian survei, peneliti mendeksripsikan secara kuantitatif kecenderungan, perilaku, atau opini dari suatu populasi (Creswell, 2016). Untuk itu, penelitian ini mendeskripsikan data jawaban dari indikator-indikator pertanyaan yang diberikan kepada responden baik berupa data kecenderungan, perilaku, maupun pendapat. Instrumen penelitian terdiri atas 17 pertanyaan mengadopsi elemen difusi inovasi yaitu inovasi (adaptasi kebiasaan baru), saluran komunikasi (interpersonal dan media), waktu (rentang waktu adopsi inovasi), dan sistem sosial (pelaku usaha). Saluran komunikasi yang menjadi indikator untuk komunikasi interpersonal yaitu sumber informasi dari pemerintah yang biasanya diberikan dalam bentuk sosialisasi. Kemudian untuk saluran media meliputi media massa dan media sosial. Waktu adopsi inovasi menggunakan konsep keinovatifan individu (Rogers, 2003) yang terdiri atas lima kategori pengadopsi: (1) inovator, (2) pengadopsi awal, (3) mayoritas awal, (4) mayoritas akhir, dan (5) lamban. Selain itu, penulis juga memasukkan indikator konfirmasi yang menjadi bagian dari proses keputusan inovasi untuk melihat komitmen responden dalam menerapkan protokol kesehatan.

Pengambilan sampel menggunakan teknik convenience sampling karena teknik ini paling mudah dilakukan dalam kondisi pandemi. Pengumpulan data dilakukan secara daring melalui Google Form pada Desember 2020 sampai Januari 2021. Data yang dikumpulkan kemudian dianalisis secara diskriptif kemudian sumber informasi dan tingkat adopsi indikator protokol kesehatan dibandingkan melalui penghitungan Weight Means Score (WMS) dengan rentang skor 1\% sampai 20\% (sangat rendah), $21 \%$ sampai $40 \%$ (rendah), $41 \%$ sampai $60 \%$ (Sedang), $61 \%$ sampai $80 \%$ (tinggi), dan $81 \%$ sampai $100 \%$ (sangat tinggi).

\section{HASIL DAN PEMBAHASAN}

\section{Profil Responden}

Responden penelitian ini berjumlah 220 orang pelaku usaha terdiri atas $40.5 \%$ laki-laki dan $59.5 \%$ perempuan dari kelompok usia generasi baby boomer $2.7 \%$, generasi X $29.5 \%$, generasi Y $60.9 \%$, dan generasi Z 6.8\%. Sebagian besar responden berpendidikan menengah $69.5 \%$ dan tinggi $26 \%$. Sebagian besar responden merupakan pelaku usaha mikro mikro $81.4 \%$, diikuti pelaku usaha kecil $16.8 \%$ dan pelaku usaha menengah $1.8 \%$.

Sebagian besar responden telah menjalankan usaha antara $1-3$ tahun $35 \%$, diikuti $<1$ tahun $34.1 \%$ dan $>3$ tahun $30.9 \%$. Dilihat dari lamanya berusaha sebagian besar merupakan pelaku usaha yang sudah 
menjalankan usahanya sebelum pandemi Covid-19. Selanjutnya berdasarkan kategori jenis usaha yang dilakukan sebagian besar merupakan pelaku usaha makanan/ minuman (41.4\%), perdagangan umum $(22.3 \%)$, dan fesyen $(17.7 \%)$. Selebihnya usaha kerajinan, informasi dan komunikasi, perbengkelan, perhotelan, dan hiburan dengan persentase masing-masing di bawah $10 \%$.

\section{Saluran Komunikasi Adaptasi Kebiasaan Baru}

Saluran komunikasi inovasi adalah suatu cara, media, atau alat yang digunakan untuk menyampaikan atau memperoleh pesan atau informasi yang bermuatan inovasi. Saluran komunikasi berperan penting dalam perubahan sosial melalui difusi inovasi (Sumardjo et al., 2019). Saluran komunikasi inovasi terdiri atas saluran komunikasi interpersonal dan media massa, di mana media massa relatif lebih penting pada tahap pengetahuan, dan saluran interpersonal relatif lebih penting pada tahap persuasi dalam proses keputusan inovasi (Rogers, 2003). Pada masa kini, saluran komunikasi inovasi bertambah dengan adanya saluran internet yang disebut media hibrida, yaitu merupakan kombinasi potensi yang ditawarkan media massa dan komunikasi interpersonal (Leeuwis, 2009). Media hibrida dapat dicontohkan sebagai media sosial karena selain dapat berfungsi sebagai media massa juga dapat digunakan untuk komunikasi interpersonal.

Membahas sumber informasi ini merupakan hal penting masa pandemi Covid-19, karena kredibilitas sumber informasi akan mempengaruhi sikap seseorang dalam merespons dan menganggapi informasi. Dalam situasi pandemi akurasi informasi penting untuk mencegah terjadinya infodemi, yaitu limpahan informasi baik online maupun offline sebagai upaya disengaja untuk menyebarkan informasi yang salah untuk merusak respons kesehatan masyarakat. Kesalahan informasi terkait pandemi ini dapat membahayakan kesehatan fisik dan mental orang, meningkatkan stigmatisasi, mengancam kesehatan, dan mendorong ketidakpatuhan terhadap protokol kesehatan, sehingga membahayakan dan mengurangi keefektifan kemampuan negara untuk menghentikan pandemi (World Health Organization, 2020).

Penelitian ini menemukan sebagian besar responden sering mendapat informasi adaptasi kebiasaan baru berupa pesan-pesan untuk mematuhi protokol kesehatan dari aktor komunikasi pemerintah (45.9\%), informasi dari media massa (56.8\%) dan media sosial (54.1\%). Dilihat jadi struktur jawaban responden, informasi dari media massa dan media sosial lebih dominan dibanding komunikasi interpersonal yang dilakukan pemerintah terutama aktor komunikasi pemerintah di tingkat daerah (Gambar 1). Meski demikian fungsi ketiga saluran komunikasi ini dalam mengkampanyekan protokol kesehatan tidak berjalan sendiri tetapi saling melengkapi. Dalam komunikasi inovasi saluran media massa umumnya lebih efektif dalam tahap pengetahuan sedangkan interpersonal pada tahap persuasi. Artinya, komunikasi yang dilakukan pemerintah dan media massa dan media sosial bukan persaingan saluran komunikasi tetapi saluran yang saling melengkapi.

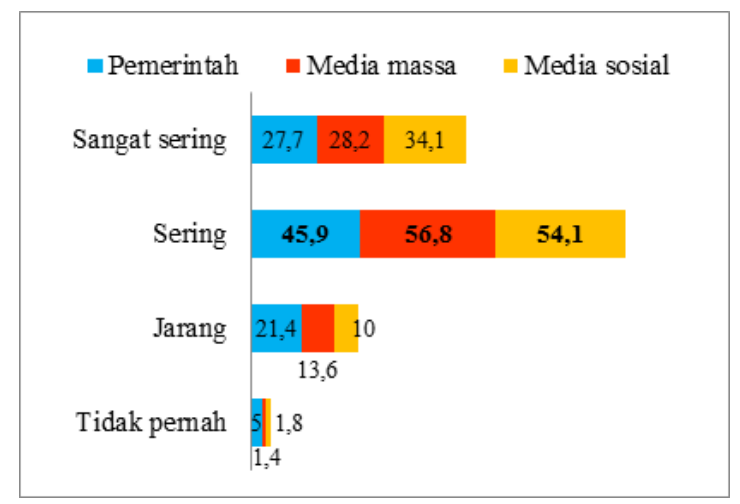

Gambar 1. Sumber informasi penerapan adaptasi kebiasan baru pelaku usaha (\%)

\section{Respons terhadap Informasi Adaptasi Kebiasaan Baru}


Komunikasi inovasi yang efektif yaitu komunikasi inovasi yang dapat mengubah pengetahuan (kognitif), sikap (afektif), dan perilaku (konatif) penerimanya. Komponen kognitif berisi persepsi, kepercayaan, dan stereotipe yang dimiliki individu mengenai sesuatu. Komponen afektif melibatkan perasaan atau emosi. Reaksi emosional ini banyak ditentukan oleh kepercayaan terhadap suatu objek, yakni kepercayaan suatu objek baik atau tidak baik, bermanfaat atau tidak bermanfaat (Zuchdi, 1995).

Respons terhadap informasi adaptasi kebiasaan baru berupa protokol kesehatan untuk pencegahan Covid-19 dapat menunjukkan tingkat pengetahuan dan sikap masyarakat terhadap pesan yang diterimanya. Pengetahuan merupakan tingkatan mendasar dalam efek komunikasi, di mana individu saat ini jika mendapat terpaan informasi umumnya dapat mengetahui pesan yang disampaikan. Setelah mengetahui informasi selanjutnya menentukan sikap atas informasi tersebut. Respons terhadap informasi dapat positif maupun negatif tergantung pada kepercayaan dan emosi individu.

Penelitian ini menemukan, sebagian besar responden (99\%) menyatakan informasi protokol kesehatan yang disampaikan oleh pemerintah maupun pihak lain yang memiliki kepedulian terhadap pencegahan penyebaran Covid-19 merupakan pesan yang penting bahkan sangat penting untuk diketahui. Pelaku usaha sebagai individu memiliki kepentingan untuk mencegah terjadinya penularan Covid-19 pada diri dan keluarganya sehingga pesan-pesan berkaitan pencegahan Covid-19 memiliki nilai. Apalagi pelaku usaha merupakan salah satu kelompok rentan karena memiliki intensitas interaksi dengan orang lain (pelanggan) yang relatif tinggi. Jika mereka mengabaikan protokol kesehatan maka risiko terjadinya penularan semakin besar (Gambar 2).

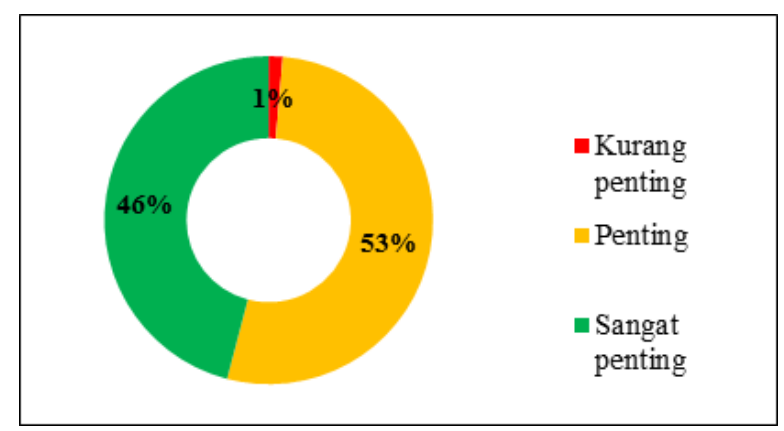

Gambar 2. Respons terhadap manfaat penerapan adaptasi kebiasan baru

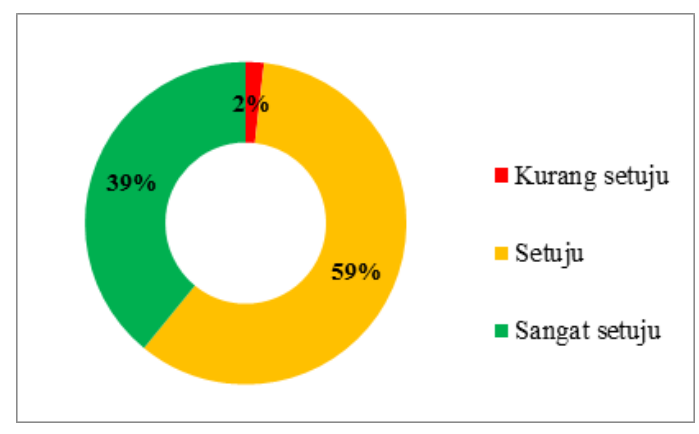

Gambar 3. Respons terhadap perubahan perilaku mematuhi adaptasi kebiasan baru

Sebagian besar responden (90\%) juga menyatakan persetujuannya untuk mematuhi protokol kesehatan pencegahan Covid-19 bagi pengusaha dan pelaku bisnis. Responden bersedia mematuhi protokol kesehatan, umumnya disebabkan dua hal yaitu karena kesadaran untuk melindungi individu dan aset usahanya serta karena adanya sanksi dari pemerintah berupa penutupan tempat usaha pagi pelanggar protokol kesehatan. Dalam setiap pemberlakuan kebijakan untuk memutus rantai penyebaran Covid19 pemerintah biasanya memberikan sanksi berupa denda maupun penutupan tempat usaha. Hal ini relatif mempengaruhi masyarakat untuk mematuhi protokol kesehatan. Apalagi pemerintah secara berkala melakukan razia untuk menjaring pelanggar protokol kesehatan, baik individu maupun pelaku usaha (Gambar 3).

\section{Perubahan Perilaku Pelaku Usaha dalam Adaptasi Kebiasaan Baru}

Perilaku merupakan reaksi psikologi seseorang terhadap lingkungannya (Sugiarto and Gabriella, 2020). Perubahan perilaku (konatif) merupakan kelanjutan dari perubahan pengetahuan dan sikap dari individu yang mendapat informasi. Komponen konatif atau kecenderungan bertindak (berperilaku) dalam diri seseorang berkaitan dengan objek sikap. Perilaku seseorang dalam situasi tertentu dan dalam situasi menghadapi stimulus tertentu, banyak ditentukan oleh kepercayaan dan perasaannya terhadap stimulus tersebut (Zuchdi, 1995). Perubahan perilaku yaitu keputusan seseorang untuk menerapkan atau tidak menerapkan protokol kesehatan sebagai adaptasi kebiasaan baru akibat pandemi Covid-19. Dalam komunikasi inovasi perilaku ini juga disebut sebagai keputusan dan 
implementasi suatu inovasi, yaitu ketika seseorang memutuskan untuk mengadopsi atau menolak dan bagi yang mengadopsi lalu mengimplementsikannya dalam tindakan nyata (Rogers, 2003).

Penelitian ini menemukan sebagian besar responden (36.4\%) menyatakan selalu menyediakan informasi kewajiban mematuhi protokol kesehatan pencegahan Covid-19 bagi karyawan/ pekerja di tempat usahanya. Sebagian besar responden (35.5\%) juga selalu menyediakan informasi kepada pelanggan di tempat usahanya untuk menghimbau mereka agar mematuhi protokol kesehatan. Pada aspek penyediaan fasilitas pendukung penerapan protokol kesehatan sebagian besar responden tidak menyediakan alat pengukur suhu tubuh (43.6\%). Sementara itu untuk penyediaan fasilitas cuci tangan sebagian besar responden selalu menyediakan (49.5\%). Begitu juga dengan penyediaan hand sanitizer sebagian besar responden selalu menyediakan (38.6\%). Untuk informasi menjaga jarak di tempat usahanya, sebagian besar responden sering menyediakan informasi (32.7\%). Temuan ini menunjukkan bahwa perilaku responden untuk menyediakan fasilitas protokol kesehatan Covid-19 relatif baik terutama penyediaan fasilitas cuci tangan. Paling rendah adalah penyediaan alat pengukur suhu tubuh karena tidak semua bersedia membelinya, terutama pelaku usaha mikro (Tabel 1).

Tabel 1. Perubahan perilaku pelaku usaha dalam adaptasi kebiasaan baru

\begin{tabular}{lcccccc}
\hline & \multicolumn{5}{c}{ Kepatuhan menerapkan protokol kesehatan } \\
\cline { 2 - 7 } & $\begin{array}{l}\text { Informasi } \\
\text { untuk } \\
\text { karyawan }\end{array}$ & $\begin{array}{l}\text { Informasi } \\
\text { untuk } \\
\text { pelanggan }\end{array}$ & $\begin{array}{l}\text { Alat } \\
\text { pengukur } \\
\text { suhu }\end{array}$ & $\begin{array}{l}\text { Fasilitas } \\
\text { cuci tangan }\end{array}$ & $\begin{array}{l}\text { Fasilitas } \\
\text { hand } \\
\text { sanitizer }\end{array}$ & $\begin{array}{l}\text { Pesan Jaga } \\
\text { jarak }\end{array}$ \\
\hline Tidak pernah & $7.7 \%$ & $10 \%$ & $43.6 \%$ & $10.9 \%$ & $15 \%$ & $24.1 \%$ \\
Kadang-kadang & $21.4 \%$ & $24.1 \%$ & $19.5 \%$ & $15.5 \%$ & $21.4 \%$ & $17.3 \%$ \\
Sering & $34.5 \%$ & $30.5 \%$ & $18.6 \%$ & $24.1 \%$ & $25 \%$ & $32.7 \%$ \\
Selalu & $36.4 \%$ & $35.5 \%$ & $18.2 \%$ & $49.5 \%$ & $38.6 \%$ & $25.9 \%$ \\
\hline
\end{tabular}

Sumber: Data primer penelitian

Selain mendeksripsikan perubahan perilaku pelaku usaha dalam penerapan protokol kesehatan, penelitian ini juga mengungkap bagaimana komunikasi para pelaku usaha untuk mewujudkan kepatuhan penerapan protokol kesehatan baik diinternal (keluarga dan karyawan) maupun eksternal (pelanggan dan mitra bisnis). Temuan penelitian ini, untuk komunikasi internal sebagian besar responden (43.2\%) selalu mengomunikasikan kepada keluarga dan karyawannya agar mereka mematuhi protokol kesehatan. Sementara itu untuk komunikasi eksternal, sebagian besar responden (34.1\%) sering mengomunikasikan protokol kesehatan kepada pelanggan.

Namun jika diamati lebih mendalam, penelitian ini menemukan $20 \%$ responden yang tidak melakukan komunikasi eksternal kepada pelanggan, seperti menegur pelanggan yang tidak memakai masker, menegur pelanggan yang tidak mau menjaga jarak, mengingatkan pelanggan untuk mencuci tangan dulu sebelum masuk ke tempat usahanya, maupun yang ekstrim melarang pelanggan yang tidak mematuhi protokol kesehatan untuk masuk atau bertransaksi (Tabel 2).

Tabel 2. Komunikasi untuk Kepatuhan Penerapan Adaptasi Kebiasan Baru

\begin{tabular}{lcc}
\hline & Komunikasi & Komunikasi \\
& Internal & Eksternal \\
\hline Tidak pernah & $3.2 \%$ & $20 \%$ \\
Kadang-kadang & $15.9 \%$ & $30 \%$ \\
Sering & $37.7 \%$ & $34.1 \%$ \\
Selalu & $43.2 \%$ & $15.9 \%$ \\
\hline
\end{tabular}

Sumber: Data primer penelitian

\section{Tingkat Keinovatifan Individu dalam Adaptasi Kebiasaan Baru}

Tingkat keinovatifan individu yaitu kategorisasi adopter inovasi untuk melihat sejauh mana seseorang atau unit adopsi lainnya relatif lebih awal dalam mengadopsi inovasi dibanding yang lainnya. Klasifikasi semacam itu adalah penyederhanaan yang membantu pemahaman tentang perilaku manusia (Rogers, 2003). Penelitian ini membagi keinovatifan individu menjadi: inovator ( $>9$ bulan), 
adopter awal (6-9 bulan), mayoritas awal (3-6 bulan), mayoritas akhir ( $<3$ bulan), dan lamban (belum menerapkan).

Penelitian ini menemukan bahwa kurva keinovatifan individu menunjukkan sebagian besar responden termasuk kategori mayoritas awal (37.3\%), yaitu mereka yang mengadopsi suatu inovasi setelah melihat banyak orang lain mengadopsi. Hal ini menunjukkan bahwa sebagian besar telah menerapkan protokol kesehatan antara 3 sampai 6 bulan sebelum penelitian dilakukan atau sejak Juni sampai September 2020. Dari temuan penelitian ini, terdapat fenomena yang perlu diperhatikan bahwa masih terdapat $7.3 \%$ responden yang belum menerapkan protokol kesehatan di tempat usahanya (Gambar 4).

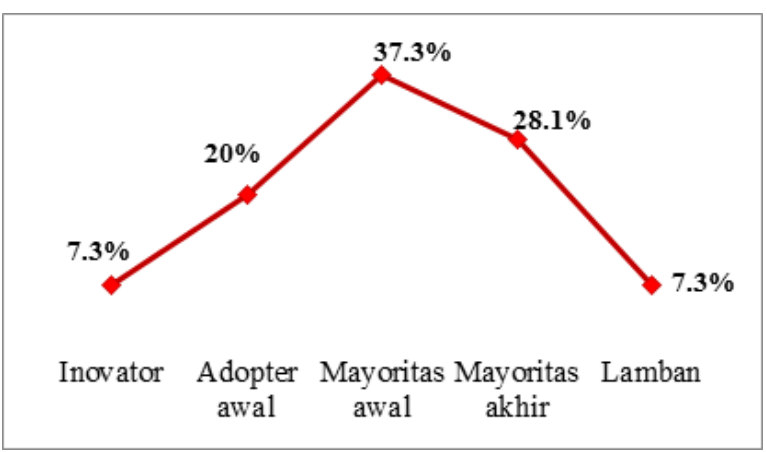

Gambar 4. Tingkat keinovatifan individu mengadopsi adaptasi kebiasan baru

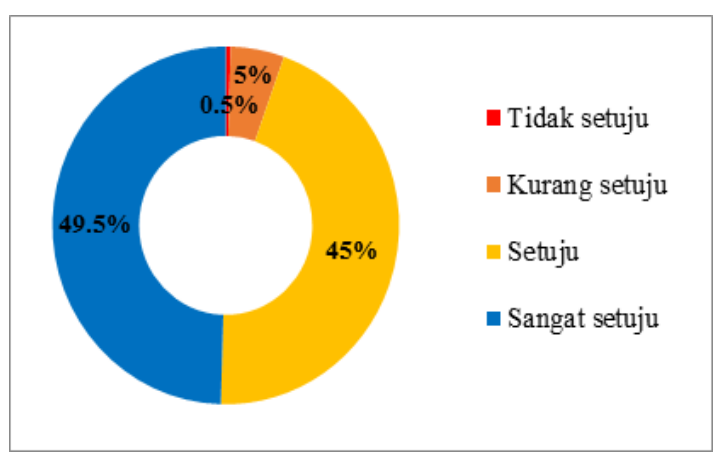

Gambar 5. Konfirmasi penerapan adaptasi kebiasan baru hingga pandemi usai

\section{Konfirmasi terhadap Adopsi Adaptasi Kebiasaan Baru}

Dalam kajian komunikasi inovasi, konfirmasi merupakan kondisi saat adopter memutuskan untuk terus melanjutkan adopsi inovasi atau menghentikannya. Pada fase ini, seseorang yang belum mengadopsi juga dapat mengubah sikapnya untuk menjadi pengadopsi. Pada fase ini unit pengambilan keputusan mencari penguatan untuk keputusan inovasi yang sudah dibuat, dan dapat membalikkan keputusan ini jika terpapar pesan yang saling bertentangan tentang inovasi (Rogers, 2003). Tahapan konfirmasi penelitian ini dijadikan indikator untuk mengetahui apakah responden terus menerapkan protokol kesehatan hingga pandemi usai atau sebaliknya. Hal ini perlu dipertanyakan sebab tidak ada yang mengetahui secara pasti kapan pandemi Covid-19 berakhir.

Penelitian ini menemukan bahwa sebagian besar responden sangat setuju (49.5\%) dan setuju (45\%) untuk menerapkan protokol kesehatan sampai pandemi Covid-19 selesai. Komitmen ini merupakan modal sosial penting dalam penerapan protokol kesehatan pada pelaku usaha yang notabene sebagai salah satu kelompok rentan penularan Covid-19. Pelaku usaha memiliki komitmen terus menerapkan protokol kesehatan karena menurut sebagian besar responden $(64.1 \%)$ protokol kesehatan pencegahan Covid-19 mudah untuk diterapkan di tempat usaha. Selain itu, sebagian besar responden $(94.5 \%)$ percaya bahwa penerapan protokol kesehatan membantu pelaku usaha agar tetap dapat berbisnis saat pandemi Covid-19 (Gambar 5).

\section{Diskusi}

Penerapan protokol kesehatan pencegahan pandemi Covid-19 sebagai adaptasi kebiasaan baru pada pelaku usaha mendapatkan beragam temuan menarik. Sebagian besar responden memberikan tanggapan positif terhadap sosialisasi penerapan protokol kesehatan pada pelaku usaha. Hal ini menunjukkan pelaku usaha di Indonesia, terutama di lokasi penelitian adaptif terhadap perubahan sosial akibat pandemi Covid-19 dan memiliki spirit yang sama dengan pemerintah untuk memutus penyebaran virus tersebut. Penilaian informasi protokol kesehatan sebagai pesan penting merupakan ciri sikap komunikatif pelaku usaha. Apalagi mereka juga bersedia mematuhi protokol kesehatan pencegahan Covid-19 sebagai adaptasi kebiasaan baru. 
Untuk mengatasi pandemi memerlukan kerja sama banyak pihak. Sebab pandemi sebagai keadaan darurat kesehatan masyarakat, krisis ekonomi, dan stabilitas pemerintahan. Sementara menangani keadaan darurat kesehatan masyarakat harus menjadi prioritas utama, kita juga perlu melihat cara penanganan krisis untuk menata ulang tatanan ekonomi dan politik yang berubah akibat pandemi (Cotula, 2021). Menghadapi situasi baru ini, hanya ada dua alternatif nyata: mencoba kembali ke normalitas yang kita ketahui sebelum pandemi, untuk menghindari dampak sosial dari tingginya tingkat pengangguran; atau untuk mempertimbangkan skenario baru ini sebagai titik balik, menandai dimulainya cara kerja baru (Carracedo, Puertas dan Marti, 2020).

Melihat fenomena yang terjadi, cara kerja baru sebagai implementasi dari adaptasi kebiasaan baru telah menjadi inovasi yang diadopsi oleh pelaku usaha. Adopsi inovasi tersebut bukan terjadi secara tiba-tiba tetapi melalui suatu proses komunikasi. Temuan penelitian menunjukkan skor tinggi (61\% sampai 80\%) pada seluruh indikator sumber informasi baik sumber informasi dari pemerintah (Informasi langsung dari Satgas Covid-19), maupun media massa (media cetak dan elektronik) dan media sosial (Facebook, Instagram, Youtube, termasuk WhatsApp Grup). Jika dibandingkan, ternyata sumber informasi media sosial memiliki skor paling tinggi dibanding sumber pemerintah dan media massa (Gambar 6).

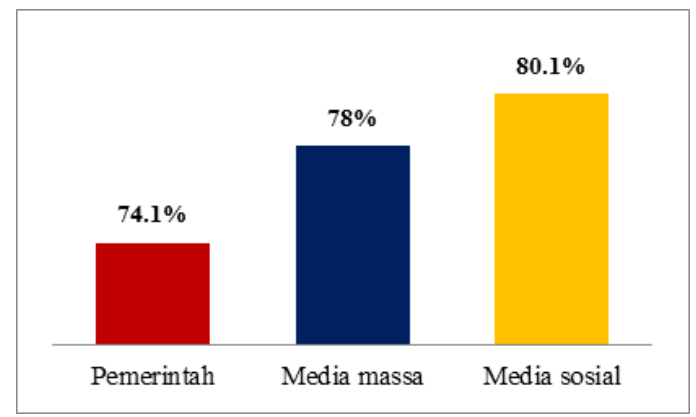

Gambar 6. Perbandingan sumber informasi adaptasi kebiasan baru

Temuan ini menunjukkan bahwa pada masyarakat kosmopolit saluran media yang bersifat massa (termasuk media sosial) relatif efektif untuk mengubah sikap hingga perilaku masyarakat. Dalam sistem sosial yang kosmopolit masyarakat sudah terbiasa mencari sumber informasi sendiri tanpa perlu menunggu dari sumber resmi pemerintah. Meski demikian dengan banyaknya informasi di media sosial perlu diwaspadai terjadinya infodemi, yaitu limpahan informasi yang salah untuk merusak respons kesehatan masyarakat. Kesalahan dalam mencari sumber informasi dan mencerna informasi dikhawatirkan dapat mengganggu upaya-upaya untuk menghentikan pandemi (World Health Organization, 2020).

Kredibilitas sumber informasi penting untuk edukasi penanganan Covid-19 termasuk pada pelaku usaha. Riset sebelumnya menemukan, meskipun pengetahuan responden tentang hoaks Covid-19 memadai, namun kebanyakan mereka ragu ketika harus membedakan hoaks atau bukan. Hal ini disebabkan limpahan informasi di media baik media massa maupun media sosial (Juditha, 2020). Apalagi, komunikasi digital dengan website dan kanal media sosial yang dibuat oleh pemerintah sejauh ini cenderung mempraktikkan pola komunikasi satu arah. Untuk itu, pemerintah dituntut dapat terlibat dalam isu atau wacana di media sosial (Oktariani dan Wuryanta, 2020). Keterlibatan pemerintah secara interaktif di media sosial diharapkan dapat menjadi "vaksin informasi" jika terjadi infodemi.

Temuan lainnya yang menarik dibahas adalah tingkat adopsi indikator protokol kesehatan yang meliputi ketersediaan informasi kewajiban mematuhi protokol kesehatan pencegahan Covid-19 bagi pekerja di tempat usahanya, ketersediaan informasi bagi pelanggan, serta ketersediaan fasilitas pendukung penerapan protokol kesehatan seperti alat pengukur suhu tubuh, fasilitas cuci tangan, hand sanitizer, dan informasi menjaga jarak. Hasil dari indikator tersebut relatif baik karena rata-rata berada pada rentang skor $61 \%$ sampai $80 \%$. Kecuali untuk penyediaan alat pengukur suhu tubuh yang berada pada skor sedang (Gambar 7). Temuan ini juga selaras dengan survei yang dilakukan BPS pada 
pertengahan tahun 2020 yang menunjukkan sebagian besar pelaku usaha telah menerapkan protokol kesehatan, seperti physical distancing, menyediakan saran cuci tangan (air, sabun dan hand sanitizer), dan sudah mewajibkan penggunaan masker atau pelindung (Badan Pusat Statistik, 2020a). Tingkat kepatuhan masyarakat dalam penerapan protokol kesehatan untuk pencegahan Covid-19 dinilai baik (Badan Pusat Statistik, 2020b).

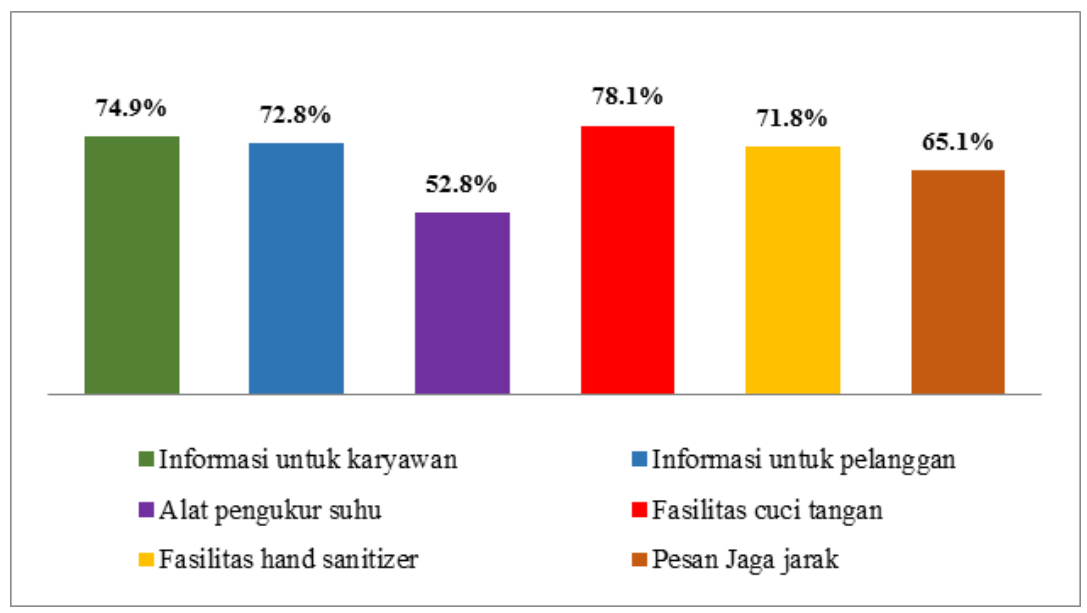

Gambar 7. Perbandingan tingkat adopsi indikator adaptasi kebiasan baru

Relatif tingginya tingkat adopsi instrumen protokol kesehatan menunjukkan pelaku UMKM di Indonesia responsif terhadap adaptasi kebiasaan baru. Apalagi sebagian besar dari pelaku usaha mengkonfirmasi untuk terus menerapkan protokol kesehatan sampai pandemi Covid-19 berakhir. Alasan mendasar pentingnya terus mengadopsi protokol kesehatan adalah mudah diterapkan di tempat usaha dan dapat membantu kelangsungan bisnis dalam situasi pandemi Covid-19. Dalam konteks ini, keterkaitannya dengan komunikasi inovasi adalah semakin mudah inovasi diimplementasikan (complexity) dan semakin tinggi manfaat (relative advantage) suatu inovasi bagi adopter maka akan mempengaruhi tingkat adopsi (Rogers, 2003). Adopsi inovasi dalam merespons bencana (termasuk Covid-19) menjadi penting karena merupakan bagian dari harmoni hubungan manusia dengan keberagaman karakteristik ruang hidupnya (Christiawan, 2014).

Berbagai temuan tersebut akhirnya meneguhkan masih besarnya modal sosial masyarakat Indonesia dalam mengatasi pandemi. Modal sosial diharapkan dapat menjadi "vaksin sosial" untuk mengatasi bencana Covid-19. Pembangunan sosial-ekonomi dapat berlangsung dengan baik jika pemerintah, dunia usaha, dan masyarakat sipil menciptakan suasana yang saling mendukung pencapaian tujuan bersama untuk mengakhiri pandemi Covid-19 (Badri, 2020). Riset sebelumnya juga menemukan bahwa modal sosial masih ada pada masa krisis meskipun terjadi perubahan budaya di masyarakat (Gandasari dan Dwidienawati, 2020). Khusus untuk pelaku UMKM, berbagai rekomendasi kebijakan juga diperlukan untuk meringankan beban mereka, termasuk perlindungan karyawan dan akurasi informasi, meningkatkan ekonomi, pendapatan dan dukungan pekerjaan, perencanaan, membangun kemampuan ketahanan, dan hubungan sosial yang positif (Shafi, Liu dan Ren, 2020). Rekomendasi itu penting diberikan karena UMKM merupakan salah satu penggerak perekonomian bangsa Indonesia dan memiliki peran yang sangat penting dalam pertumbuhan ekonomi serta penyerapan tenaga kerja di Indonesia (Lestari, Yulinartati dan Fitriya, 2019).

\section{KESIMPULAN}

Penelitian tentang komunikasi inovasi dalam adaptasi kebiasaan baru pada kalangan pelaku usaha menemukan media sosial merupakan sumber informasi dengan skor tinggi yang digunakan untuk mendapatkan informasi tentang perkembangan penanganan Covid-19 dan penerapan protokol kesehatan. Temuan ini menunjukkan bahwa pelaku usaha merupakan kelompok kosmopolit yang melek teknologi sehingga saluran berbasis internet dapat digunakan sebagai saluran komunikasi yang efektif. Pelaku usaha juga memberikan respons yang baik terhadap kebijakan penerapan protokol 
kesehatan pada dunia usaha, karena pelaku usaha menunjukkan tingginya adopsi terhadap indikator protokol kesehatan. Sebagian besar pelaku usaha juga memiliki komitmen untuk tetap menerapkan protokol kesehatan di lingkungan usahanya untuk menghindari penularan dan menjaga kelangsungan usahanya.

Untuk meningkatkan adopsi adaptasi kebiasaan baru dalam jangka panjang penulis menyarankan agar pemerintah lebih banyak melakukan komunikasi kepada pelaku usaha baik secara langsung maupun melalui media sosial. Meski temuan penelitian sudah dapat menggambarkan tujuan penelitian tetapi penelitian ini memiliki keterbatasan belum menggali lebih mendalam komunikasi inovasi secara kualitatif, terutama untuk mendalami faktor sosial dan budaya yang melatar belakangi keputusan inovasi.

\section{UCAPAN TERIMA KASIH}

Penulis mengucapkan terima kasih kepada mahasiswa kelas Komunikasi Inovasi 2020/ 2021 yang membantu proses pengumpulan data primer sebagai enumerator.

\section{DAFTAR PUSTAKA}

Aisha, S. and Mulyana, D. (2020) 'International Students' Communication Adaptation to Academic Environment in the United Kingdom', Jurnal Penelitian Komunikasi, 23(2), pp. 101-112. doi: https://doi.org/10.20422/jpk.v2i23.678.

Badan Pusat Statistik (2020a) Analisis Hasil Survei Dampak Covid-19 Terhadap Pelaku Usaha. Jakarta: BPS RI.

Badan Pusat Statistik (2020b) Perilaku Masyarakat Di Masa Pandemi Covid-19. Jakarta: BPS RI.

Badri, M. (2020) Menggerakkan Modal Sosial Atasi Bencana Corona. Available at: https://news.detik.com/kolom/d-4962462/menggerakkan-modal-sosial-atasi-bencana-corona (Accessed: 6 August 2020).

BPS Provinsi Riau (2020) Dampak Covid-19 Terhadap Kondisi Sosial Masyarakat di Provinsi Riau. Pekanbaru: BPS Provinsi Riau.

Carracedo, P., Puertas, R. and Marti, L. (2020) 'Research lines on the impact of the COVID-19 pandemic on business. A text mining analysis', Journal of Business Research. doi: 10.1016/j.jbusres.2020.11.043.

Christiawan, P. I. (2014) 'Inovasi Pendidikan Bencana Berbasis Pendekatan Spasial di Indonesia', Media Komunikasi Geografi, 15(1), pp. 1-18. doi: http://dx.doi.org/10.23887/mkg.v15i1.11419.

Cotula, L. (2021) 'Towards a political economy of the COVID-19 crisis: Reflections on an agenda for research and action', World Development, 138, p. 105235. doi: 10.1016/j.worlddev.2020.105235.

Creswell, J. W. (2016) RESEARCH DESIGN: Pendekatan Metode Kualitatif Kuantitatif dan Campuran. 4th edn. Yogyakarta: Pustaka Pelajar.

Gandasari, D. and Dwidienawati, D. (2020) 'Content analysis of social and economic issues in Indonesia during the COVID-19 pandemic', Heliyon, 6(11), p. e05599. doi: 10.1016/j.heliyon.2020.e05599.

Hubeis, A. V. S. et al. (2016) Komunikasi Inovasi. 2nd edn. Tangerang Selatan: Universitas Terbuka.

Juditha, C. (2020) 'People Behavior Related To The Spread Of Covid-19's Hoax', Journal Pekommas, 5(2), p. 105. doi: 10.30818/jpkm.2020.2050201.

Kementerian Kesehatan (2020) Menuju Adaptasi Kebiasaan Baru. Available at: https://promkes.kemkes.go.id/menuju-adaptasi-kebiasaan-baru (Accessed: 1 April 2021).

Kementerian Komunikasi dan Informatika (2020) Adaptasi Kebiasaan Baru, Apa yang Harus Kamu Ketahui? Available at: https://kominfo.go.id/content/detail/27276/adaptasi-kebiasaan-baru-apayang-harus-kamu-ketahui/0/virus_corona (Accessed: 1 April 2021). 
Kirk, C. P. and Rifkin, L. S. (2020) 'I'll trade you diamonds for toilet paper: Consumer reacting, coping and adapting behaviors in the COVID-19 pandemic', Journal of Business Research, 117, pp. 124-131. doi: 10.1016/j.jbusres.2020.05.028.

Leeuwis, C. (2009) Komunikasi Untuk Inovasi Pedesaan. Yogyakarta: Kanisius.

Lestari, A. D., Yulinartati, Y. and Fitriya, E. (2019) 'Rekonstruksi Laporan Keuangan Berbasis Standar Akuntansi Keuangan Entitas Mikro, Kecil dan Menengah', Jurnal Ilmu Sosial dan Humaniora, 8(1), p. 7. doi: 10.23887/jish-undiksha.v8i1.21348.

Megatsari, H. et al. (2020) 'The community psychosocial burden during the COVID-19 pandemic in Indonesia', Heliyon, 6(10), p. e05136. doi: 10.1016/j.heliyon.2020.e05136.

Nordhagen, S. et al. (2021) 'COVID-19 and small enterprises in the food supply chain: Early impacts and implications for longer-term food system resilience in low- and middle-income countries', World Development, 141, p. 105405. doi: 10.1016/j.worlddev.2021.105405.

Oktariani, R. and Wuryanta, A. E. W. (2020) 'Komunikasi Pemerintah Melalui Media Center Gugus Tugas Percepatan Penanganan Covid-19 Kepada Publik', Expose: Jurnal Ilmu Komunikasi, 3(2), p. 113. doi: 10.33021/exp.v3i2.1196.

Pantano, E. et al. (2020) 'Competing during a pandemic? Retailers' ups and downs during the COVID-19 outbreak', Journal of Business Research, 116, pp. 209-213. doi: 10.1016/j.jbusres.2020.05.036.

Rogers, E. M. (2003) Diffusion of innovations. 5th edn. New York: Free Press.

Satuan Tugas Penanganan Covid-19 (2020) Panduan Bagi Pengusaha dan Bisnis. Available at: https://covid19.go.id/edukasi/materi-edukasi/panduan-bagi-pengusaha-dan-bisnis (Accessed: 1 April 2021)

Shafi, M., Liu, J. and Ren, W. (2020) 'Impact of COVID-19 pandemic on micro, small, and mediumsized Enterprises operating in Pakistan', Research in Globalization, 2, p. 100018. doi: 10.1016/j.resglo.2020.100018.

Shaw, R., Kim, Y. and Hua, J. (2020) 'Governance, technology and citizen behavior in pandemic: Lessons from COVID-19 in East Asia', Progress in Disaster Science, 6, p. 100090. doi: 10.1016/j.pdisas.2020.100090.

Soon, J. M. et al. (2021) 'Food safety and evaluation of intention to practice safe eating out measures during COVID-19: Cross sectional study in Indonesia and Malaysia', Food Control, p. 107920. doi: 10.1016/j.foodcont.2021.107920.

Sugiarto, A. and Gabriella, D. A. (2020) 'Kesadaran Dan Perilaku Ramah Lingkungan Mahasiswa di Kampus', Jurnal Ilmu Sosial dan Humaniora, 9(2), p. 260. doi: 10.23887/jishundiksha.v9i2.21061.

Sumardjo et al. (2019) Komunikasi Inovasi. 3rd edn. Tangerang Selatan: Universitas Terbuka.

World Health Organization (2020) Managing the COVID-19 infodemic: Promoting healthy behaviours and mitigating the harm from misinformation and disinformation. Available at: https://www.who.int/news/item/23-09-2020-managing-the-covid-19-infodemic-promotinghealthy-behaviours-and-mitigating-the-harm-from-misinformation-and-disinformation (Accessed: 7 February 2021).

Zuchdi, D. (1995) 'Pembentukan Sikap', Cakrawala Pendidikan, 14(3), pp. 51-63. 